\title{
Soil-gas survey of liquefaction and collapsed caves during the Emilia seismic sequence
}

\author{
Alessandra Sciarra ${ }^{\star}$, Barbara Cantucci, Mauro Buttinelli, Gianfranco Galli, Manuela Nazzari, \\ Luca Pizzino, Fedora Quattrocchi
}

Istituto Nazionale di Geofisica e Vulcanologia, Sezione Roma 1, Roma, Italy

\author{
Article history \\ Received July 20, 2012; accepted September 11, 2012. \\ Subject classification: \\ Gas geochemistry, Geochemical exploration, Gases, Soil-gas measurements and monitoring, Liquefaction.
}

\section{Introduction}

The epicentral area of the Emilia seismic sequence is located in the Emilia-Romagna Region (northern Italy), $45 \mathrm{~km}$ from the city of Modena (Figure 1). This area is sited within thrust-related folds of the Ferrara Arc, which represent the most external part of the northern Apennines. This sector is considered as having been active during late Pliocene to early Pleistocene times [Scrocca et al. 2007] and encompasses also the Mirandola and Ferrara seismogenic sources [e.g., Burrato et al. 2003, Boccaletti et al. 2004, Basili et al. 2008].

The main sedimentary infilling of the Po Plain is represented by Pliocene-Pleistocene alluvial deposits (alternating fluvial sands and clays) that overlie a foredeep clastic sequence, with a total average thickness of $2 \mathrm{~km}$ to $4 \mathrm{~km}$ [e.g., Carminati et al. 2010].

Soon after the mainshock, several liquefaction phenomena coupled to ground fractures were observed in the epicentral area (e.g., San Carlo, Ferrara). Soil liquefaction is a phenomenon in which the strength and stiffness of a soil is reduced by earthquake shaking or other rapid loading. Liquefaction generally occurs in saturated unconsolidated sediments (e.g., sand, mud, and artificial fill) that lose their shear strength [Hazen 1920]. As a consequence, liquefied soil cannot support differential stress, thus causing ground failure and damage to the built environment.

Several soil measurements of gas fluxes $\left(\mathrm{CO}_{2}\right.$ and $\left.\mathrm{CH}_{4}\right)$ and concentrations were performed on liquefactions and ground fractures located in the Finale Emilia (Modena) area (Via Fruttarola and Santa Bianca) and the Ferrara area (Renazzo and San Carlo) (Figures 1, 2) to determine whether these diffuse phenomena can be correlated with deep fluid migration through preferential leakage pathways linked to the earthquake.

To determine the possible leakage induced by the seismic stress during the Emilia sequence, collapsed caves in the epicentral area were also sampled. These collapse phenom- ena are linked to gas escape, and have been known since the 1970 's in some tectonically active areas of the southern Po Plain [Bonori et al. 2000]. Individual phenomena occur as localized depressions of the soil in the shape of the cavity, or an 'inverted funnel', or as wide slits that are broad and up to few meters deep (Figure 3). Collapsed caves are considered as superficial events that are likely to have been triggered by compaction of organic-matter-rich soils (e.g., peat) [Castellarin et al. 2006]. Complex microbial (bacteria) reactions transform the peat, resulting in volume loss and a consequent slight ground subsidence. Collapsed caves generally develop in orchards, mainly due to the loss of cohesion of the soil, its extreme imbibition, or the transit of agricultural vehicles.

Collapsed caves reported in the literature and/or local press [e.g., Febo 1999, Martelli 2002] in the epicentral area were previously investigated by our research group in 2008 , with several soil measurements of $\mathrm{CO}_{2}$ and $\mathrm{CH}_{4}$ fluxes. Immediately after the May 20, 2012, mainshock and during the Emilia seismic sequence, the collapsed caves were sampled again to determine any variations in these $\mathrm{CO}_{2}$ and $\mathrm{CH}_{4}$ fluxes. In this survey, newly formed collapsed caves were also found and measured (especially in the northern part of investigated area).

\section{Methods}

$\mathrm{CO}_{2}$ and $\mathrm{CH}_{4}$ fluxes were measured by the speedportable 'closed dynamic' accumulation chamber 'time zero' method [e.g., Cardellini et al. 2003] using a West System instrument equipped with $\mathrm{CO}_{2}$ and $\mathrm{CH}_{4}$ infrared detectors. The recorded concentrations measured over time, combined with other parameters such as volume and surface of the accumulation chamber, allowed the calculation of the exhalation flux from the soil [e.g., Hutchinson et al. 2000].

Soil-gas samples were collected using a steel probe that was driven into the ground to a depth of $0.6 \mathrm{~m}$ to $0.8 \mathrm{~m}$, to avoid the major influence of meteorological variables [e.g., Hinkle 1994]. The soil-gas concentrations $\left(\mathrm{CO}_{2}, \mathrm{CH}_{4}, \mathrm{He}\right)$ 


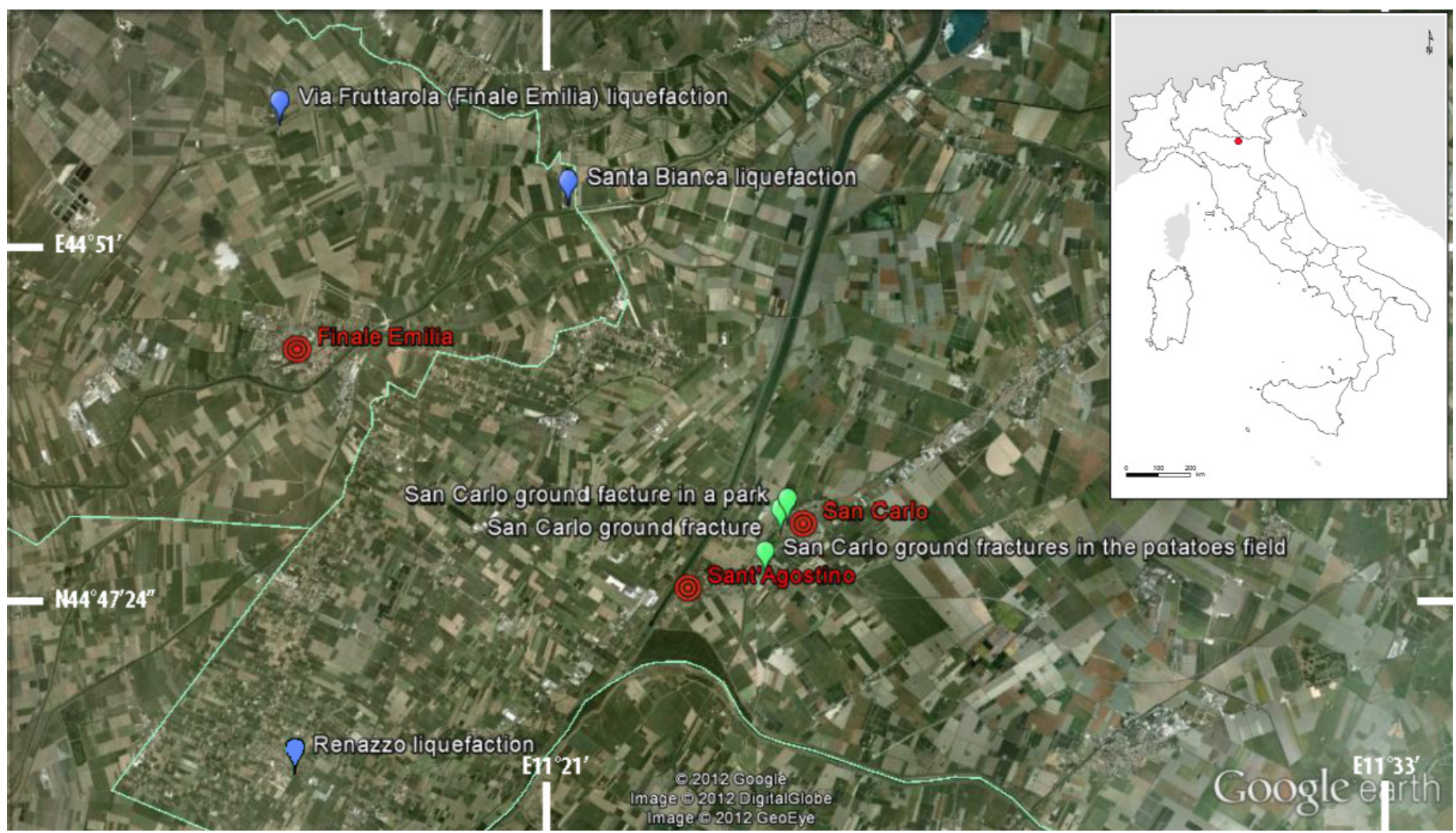

Figure 1. Location map of the sampled liquefactions (blue) and ground fractures (green). Geographic coordinates WGS 84.

were analyzed in the laboratory using a MicroGC Varian 4009 CP, equipped with thermal conductivity detectors. Radon was analyzed immediately in the field, due to its halflife (3.8 days), using a RAD7 Durridge alpha spectrometry instrument, at a depth of $70 \mathrm{~cm}$.

\section{Results and discussion}

\subsection{Soil liquefaction and ground fractures}

In the epicentral area (e.g., San Carlo, Ferrara) soil liquefaction and sand blows were coupled to ground fractures that also showed noticeable horizontal and vertical displacements, and were observed at sites with young alluvium. A mixture of gray-colored fine particle materials and water bubbled up into streets, parks and fields, and even through the concrete floors of buildings.

The soil liquefaction and ground fractures followed two preferential alignments (N60W and N140W) which can be related both to the main directions of the buried fold axes and to paleo-river bed structures in the area.

Measurements of fluxes $\left(\phi \mathrm{CO}_{2}\right.$ and $\left.\phi \mathrm{CH}_{4}\right)$ and soil-gas concentrations $\left(\mathrm{CO}_{2}, \mathrm{CH}_{4}, \mathrm{He},{ }^{222} \mathrm{Rn}\right)$, as well as the main statistical parameters, are reported in Tables 1 and 2, respectively. These data were compared both to previous soil-gas measurements performed by the authors in 2006 in the area between Rivara and Massa Finalese (Modena) (unpublished data), and to two case studies in central Italy [Annunziatellis et al. 2008] and in foredeep basins [Ciotoli et al. 2007].

The $\mathrm{CO}_{2}$ concentrations after the May 20, 2012, earth- quake decreased with respect to the Rivara 2006 ones, aligning with those reported in Annunziatellis et al. [2008].

The He and ${ }^{222} \mathrm{Rn}$ contents did not show any remarkable variations when compared to the 2006 data, and they were lower than the concentrations measured in other Italian sites [Ciotoli et al. 2007, Annunziatellis et al. 2008]. Negative $\mathrm{He}$ values (i.e., values lower than the atmospheric reference) constituted the bulk of our dataset. In spite of what was claimed by Reimer [1990] and Duddridge et al. [1991], negative anomalies did not appear to be linked to tectonic or morphological features. Several studies have reported He values below the air concentrations [e.g., Reimer 1980, Lombardi and Voltattorni 2010], which suggests a shallow origin of this gas. Therefore, negative He values can result from a disequilibrium between the soil gases and the atmosphere, as a consequence of differential mobility of the gaseous species involved [Ciotoli et al. 1999].

Radon is generally used as a tracer to provide a qualitative idea of gas transfer (velocity and flux), and its characteristics allow it to be used as a tool for mapping active faults in seismotectonic environments. In our samples, radon showed low values and was very similar to the Rivara data, indicating an absence of any deep fluid leakage.

$\mathrm{CH}_{4}$ showed mean and median values clearly higher than the Rivara 2006 data (224.61, 6.01 and $14.65 \mathrm{ppmv} / \mathrm{v}$, respectively). The highest $\mathrm{CH}_{4}$ concentrations were measured for the ground fractures at San Carlo (890 ppm), and for the soil liquefaction in Via Fruttarola (434 ppm) and Renazzo (338 ppm).

San Carlo showed the highest $\mathrm{CH}_{4}$ values, which were 


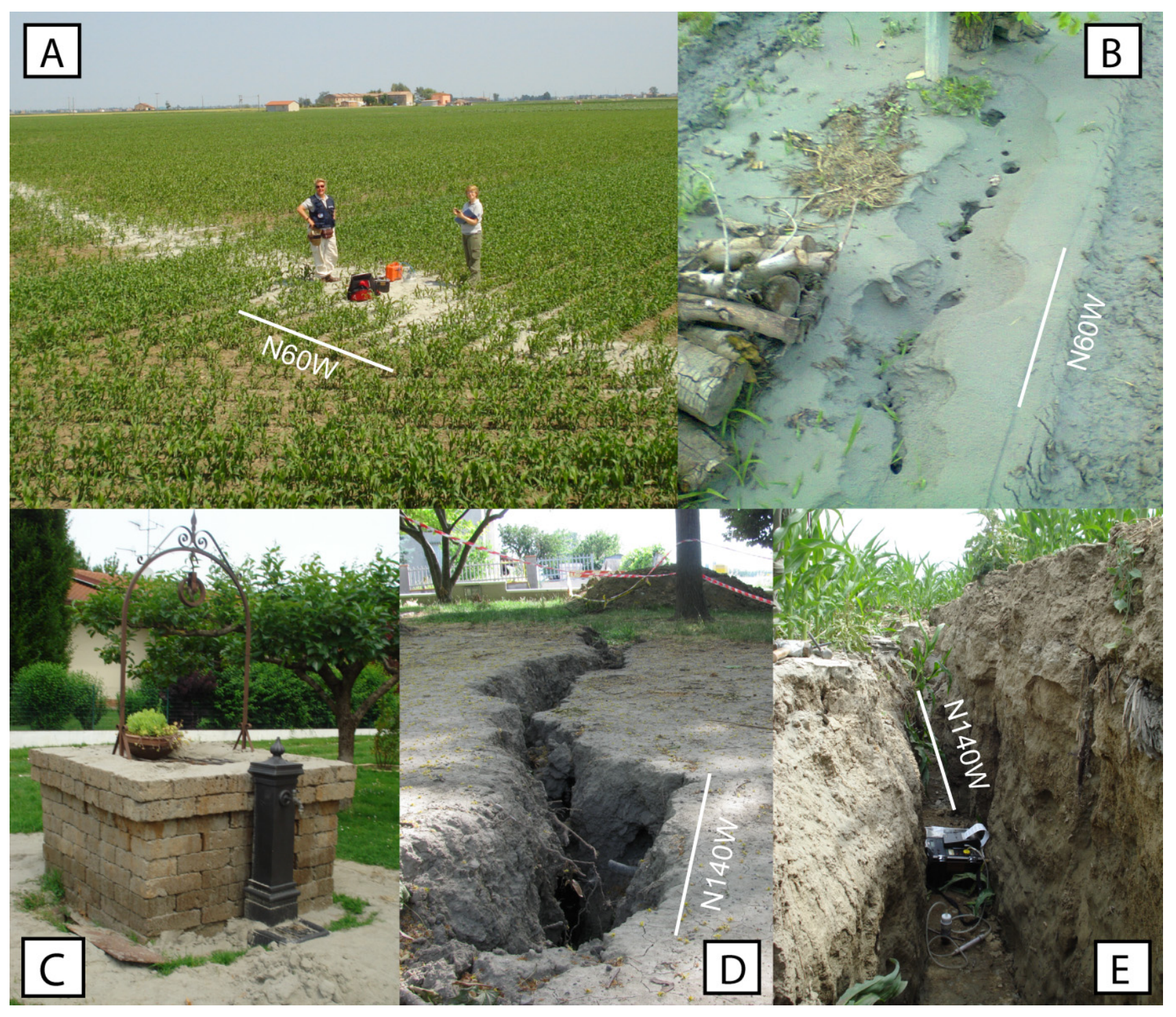

Figure 2. A, B. Liquefactions with N60W direction observed in Via della Fruttarola-Finale Emilia (Modena) corn field and Santa Bianca (Modena), respectively. C. Sand blowout from a well in San Carlo (Ferrara). D, E. Ground fractures with a N140W direction observed in the San Carlo area (Ferrara) soon after May 20, 2012 (see Figure 1 for location map). Geographic coordinates UTM WGS 84 32N.

\begin{tabular}{lccccc}
\hline Sampling site - Emilia 2012 & $\begin{array}{c}\mathbf{C O}_{2} \\
(\mathbf{\% v} / \mathbf{v})\end{array}$ & $\begin{array}{c}\mathbf{C H}_{4} \\
(\mathbf{p p m v} / \mathbf{v})\end{array}$ & $\begin{array}{c}\mathbf{H e} \\
(\mathbf{p p m v} / \mathbf{v})\end{array}$ & $\begin{array}{c}\mathbf{R n} \\
\left(\mathbf{B q} / \mathbf{m}^{3}\right)\end{array}$ & $\begin{array}{c}\phi \mathbf{C O}_{2} \\
\left(\mathbf{g} / \mathbf{m}^{2} \mathbf{d a y}\right)\end{array}$ \\
\hline Renazzo Liquefaction 01 & 6.03 & 337.80 & 3.69 & - & 30.669 \\
$\left(\mathbf{g} / \mathbf{m}^{2} \mathbf{d a y}\right)$
\end{tabular}

Table 1. Measurements of fluxes and soil-gas concentrations for liquefactions and ground fractures in the Finale Emilia (Modena) area (Via Fruttarola and Santa Bianca), and in the Ferrara area (Renazzo and San Carlo), during 2012 earthquake sequence. 


\begin{tabular}{|c|c|c|c|c|c|c|}
\hline Data & N. & Mean & Median & Minimum & Maximum & Std. Dev. \\
\hline \multicolumn{7}{|l|}{ Emilia 2012} \\
\hline $\mathrm{CO}_{2}(\% \mathrm{v} / \mathrm{v})$ & 8 & 1.839 & 0.87 & 0.17 & 6.03 & 2.11 \\
\hline $\mathrm{CH}_{4}(\mathrm{ppmv} / \mathrm{v})$ & 8 & 224.61 & 53.66 & 4.03 & 890.38 & 313.99 \\
\hline $\mathrm{He}(\mathrm{ppmv} / \mathrm{v})$ & 8 & 4.453 & 4.39 & 3.69 & 5.51 & 0.657 \\
\hline $\mathrm{Rn}\left(\mathrm{Bq} / \mathrm{m}^{3}\right)$ & 6 & 4762 & 2020 & 1700 & 18400 & 6687 \\
\hline$\phi \mathrm{CO}_{2}\left(\mathrm{~g} / \mathrm{m}^{2}\right.$ day $)$ & 13 & 16.88 & 10.76 & 2.301 & 77.283 & 19.90 \\
\hline$\phi \mathrm{CH}_{4}\left(\mathrm{~g} / \mathrm{m}^{2}\right.$ day $)$ & 13 & 1.82 & 1.719 & 0.00 & 4.569 & 1.411 \\
\hline \multicolumn{7}{|l|}{ Rivara 2006} \\
\hline $\mathrm{CO}_{2}(\% \mathrm{v} / \mathrm{v})$ & 24 & 2.31 & 1.59 & 0.11 & 7.21 & 2.06 \\
\hline $\mathrm{CH}_{4}(\mathrm{ppmv} / \mathrm{v})$ & 24 & 6.01 & 0.15 & 0.00 & 134.62 & 27.40 \\
\hline $\mathrm{He}(\mathrm{ppmv} / \mathrm{v})$ & 24 & 4.99 & 4.98 & 4.69 & 5.44 & 0.17 \\
\hline $\mathrm{Rn}\left(\mathrm{Bq} / \mathrm{m}^{3}\right)$ & 24 & 4854 & 2790 & 0 & 16400 & 5288 \\
\hline$\phi \mathrm{CO}_{2}\left(\mathrm{~g} / \mathrm{m}^{2}\right.$ day $)$ & 231 & 21.27 & 13.76 & 0.43 & 211 & 26.19 \\
\hline$\phi \mathrm{CH}_{4}\left(\mathrm{~g} / \mathrm{m}^{2}\right.$ day $)$ & 231 & 0.67 & 0.02 & 0.00 & 30.27 & 3.02 \\
\hline \multicolumn{7}{|l|}{ Italian data } \\
\hline $\mathrm{CO}_{2}^{\star}(\% \mathrm{v} / \mathrm{v})$ & 16301 & 1.93 & 0.83 & 0.03 & 100 & 6.09 \\
\hline $\mathrm{CH}_{4}^{\star}(\mathrm{ppmv} / \mathrm{v})$ & 11945 & 14.65 & 1.83 & 0.01 & 19396.14 & 263.10 \\
\hline $\mathrm{He}^{\star}(\mathrm{ppmv} / \mathrm{v})$ & 38060 & 5.48 & 5.31 & 1.20 & 315.22 & 2.95 \\
\hline $\mathrm{Rn}^{\#}\left(\mathrm{~Bq} / \mathrm{m}^{3}\right)$ & 2359 & 19100 & 12900 & 370 & 241200 & 22900 \\
\hline
\end{tabular}

Table 2. Flux and soil-gas statistics for liquefactions and ground fractures in the epicentral area, compared both to previous soil-gas statistics obtained by the authors in 2006 in the area between Rivara and Massa Finalese (Modena) (unpublished data), and to the statistics obtained for two case studies in central Italy and in foredeep basins. ${ }^{\star}$, soil-gas statistics taken from Annunziatellis et al. [2008]; ${ }^{\#}$, radon data measured in foredeep basins from Ciotoli et al. [2007].

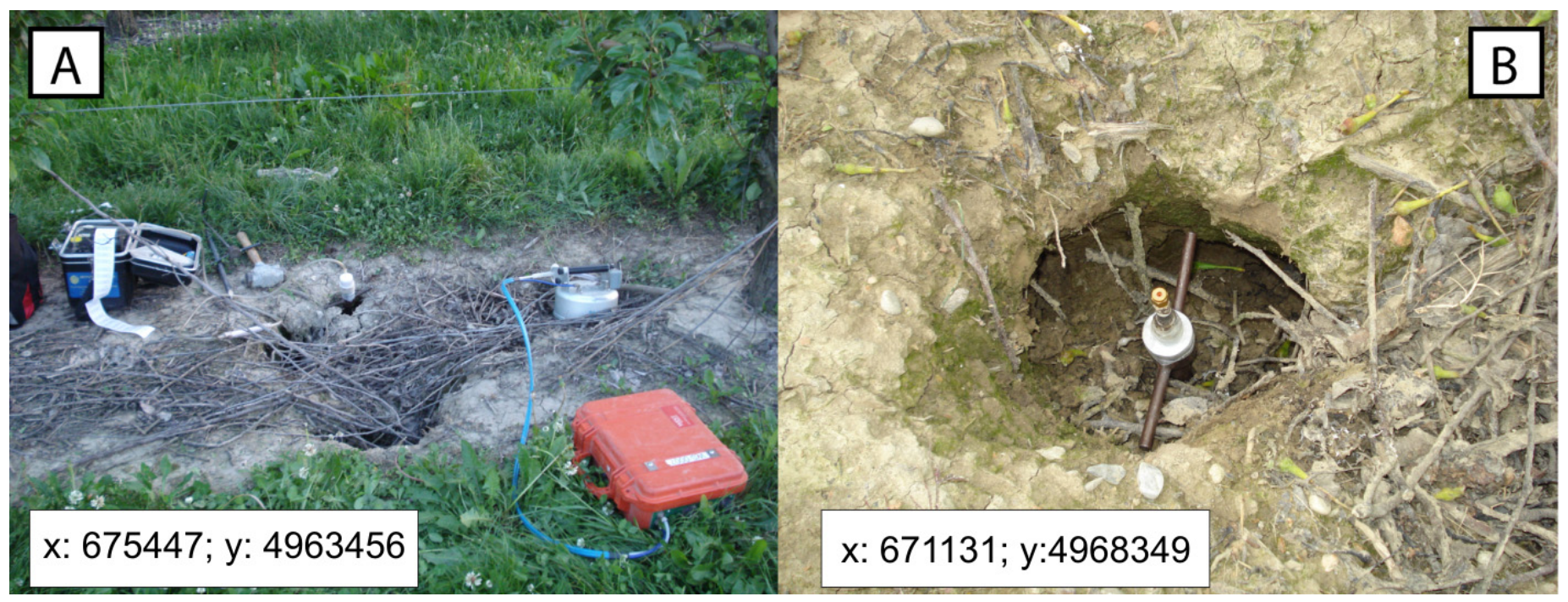

Figure 3. A, B. Soil-gas and flux measurements in collapsed caves. B. Detail of the steel probe driven into the collapsed caves to collect soil-gas samples. Geographic coordinates UTM WGS 84 32N.

not correlated with other pathfinder elements (e.g., ${ }^{222} \mathrm{Rn}$ and $\mathrm{He}$ ) [Lombardi and Voltattorni 2010]. This might suggest a local anomaly, which would be likely to be due to surficial layer compression during the earthquake.

For Via Fruttarola and Renazzo liquefactions, the high $\mathrm{CH}_{4}, \mathrm{CO}_{2}$ and ${ }^{222} \mathrm{Rn}$ concentrations were correlated with each other (Table 1). Moreover, high values of $\phi \mathrm{CO}_{2}$ and $\phi \mathrm{CH}_{4}$ were well correlated with $\mathrm{CH}_{4}$ at Renazzo. These positive correlations among various gaseous species support the theory that $\mathrm{CO}_{2}$ acts as a carrier for trace gases like radon [Durrance and Gregory 1990, Hermansson et al. 1991, Etiope and Lombardi 1995, Quattrocchi et al. 1999, Beaubien et al. 2003, Ciotoli et al. 2005, Lombardi and Voltattorni 2010].

The $\delta^{13} \mathrm{C}$ analyses were carried out only in the San Carlo sample (over the minimum of detection for the analyses: $450 \mathrm{ppm}$ ), which indicated a prevalent biogenic origin $\left(\delta^{13} \mathrm{C}=-67.25 \%\right.$ vs. Pee Dee Belemnite [PDB] standard; $\delta \mathrm{D}=-164.77 \%$ vs. Standard Mean Ocean Water [SMOW] 

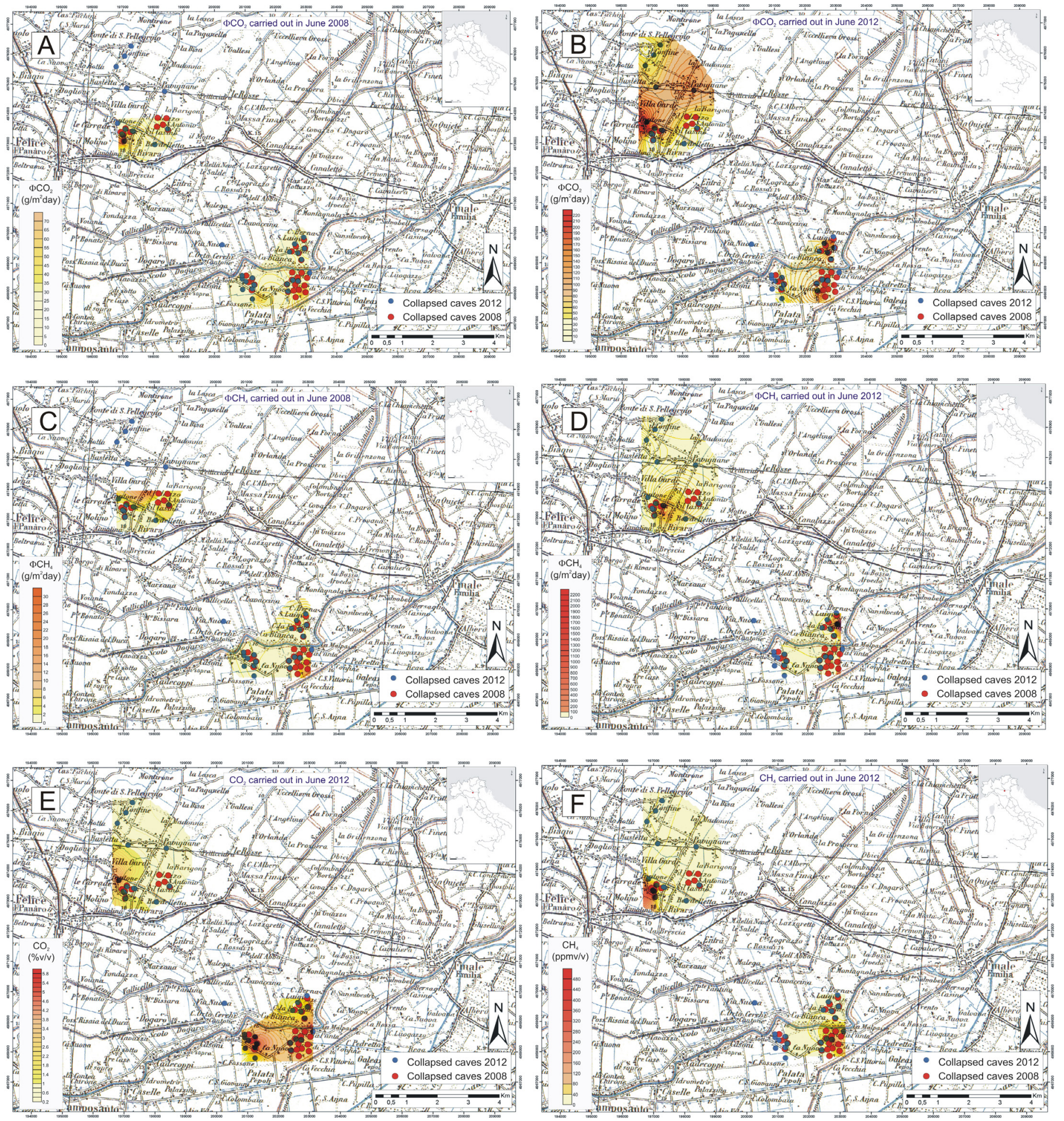

Figure 4. Collapsed cave contour maps in the Finale Emilia, Camposanto and Ponte San Pellegrino areas (Modena). A, B. $\phi \mathrm{CO}_{2}$ measured in 2008 and 2012, respectively. C, D. $\phi \mathrm{CH}_{4}$ measured in 2008 and 2012, respectively. E. $\mathrm{CO}_{2}$ concentrations measured in 2012. $\mathrm{F}_{\text {. }} \mathrm{CH}_{4}$ concentrations measured in 2012. Green dots, 2008 sampling points; red dots, 2012 sampling points. The areal distribution has different extents due to different numbers of sampling points in 2008 and 2012.

standard). The concentrations of lighter hydrocarbons were below the detection limit ( $2 \mathrm{ppm})$ in all of the samples, which suggested a low-temperature origin of $\mathrm{CH}_{4}$ (i.e., shallow and biogenic production).

The flux measurements of $\mathrm{CO}_{2}$ and $\mathrm{CH}_{4}$ after the mainshock showed the same trends as the soil-gas concentrations. The $\phi \mathrm{CO}_{2}$ values fit those measured in 2006, while the $\phi \mathrm{CH}_{4}$ mean and median were higher.

The $\mathrm{CO}_{2}$ values were within the typical range of vegetative exhalation of the cultivated soil [Baldocchi and Meyers 1991], minimizing its provenance from depth. The increased methane fluxes can be linked to the methane concentrations, and can be explained by the presence of peat layers in the most shallow strata. 


\subsection{Collapsed caves}

Collapsed caves (Figure 3) in the epicentral area were sampled both in June 2008 and June 2012, with stable and dry weather conditions. The 2012 measurements were repeated in the same spot as those of 2008 when this still existed after four years, as well as in newly discovered collapsed caves.

All of the data were processed with a statistical approach using normal probability plots, to define the statistical populations for each parameter, and to compute the contour maps using experimental kriging (Figure 4).

The spatial distributions of the soil-gas concentrations and fluxes measured in 2008 and 2012 are shown in Figure 4. A comparison between the $\mathrm{CO}_{2}$ fluxes of 2008 (Figure 4A) with those measured in 2012 (Figure $4 \mathrm{~B}$ ) shows a remarkable increase over time. The areal distribution of anomalous values is very similar, but the maximum $\mathrm{CO}_{2}$ flux changed from $70 \mathrm{~g} / \mathrm{m}^{2}$ day to $220 \mathrm{~g} / \mathrm{m}^{2}$ day. The $\phi \mathrm{CH}_{4}$ showed the greater variations, going from $30 \mathrm{~g} / \mathrm{m}^{2}$ day to $2200 \mathrm{~g} / \mathrm{m}^{2}$ day. These higher $\phi \mathrm{CH}_{4}$ values in both 2008 and 2012 were in the southern part of the investigated area, close to the Panaro River (Ca' Bianca locality).

In the northern part of the study area (Villa Gardè locality), the anomalous $\mathrm{CO}_{2}$ and $\mathrm{CH}_{4}$ concentrations, which were higher than the Italian averages [Annunziatellis et al. 2008], corresponded to the maximum values of $\phi \mathrm{CO}_{2}$.

In the southern part, a positive correlation was highlighted between the anomalous $\mathrm{CH}_{4}$ concentrations and the maximum values of $\phi \mathrm{CO}_{2}$. The highest $\mathrm{CO}_{2}$ and $\mathrm{CH}_{4}$ concentrations were found south of the Panaro River, between the Ca' Nuova and Palata Pepoli localities. The presence of anomalous values in collapsed caves close to the Panaro River suggests a surficial origin of these phenomena, which is likely to be due to redox processes in the alluvial sediments. Conversely, in the northern part of the investigated area, isotopic analyses aimed at determining the origin of the $\mathrm{CH}_{4}$ were performed on a sample $\left(\mathrm{CH}_{4}=522.6 \mathrm{ppmv} / \mathrm{v}\right)$, which highlighted a prevalent shallow biogenic origin $\left({ }^{13} \mathrm{C}=-59.64 \%\right.$ vs. PDB; $\delta \mathrm{D}=-153.39 \%$ vs. SMOW $)$. Therefore, the anomalous gas concentrations in collapsed caves is likely to be correlated to decomposition of shallow peat and/or lignite layers, which produce $\mathrm{CH}_{4}$ through microbial activity [Bonori et al. 2000].

\section{Conclusions and remarks}

Soon after the May 20, 2012, mainshock $\left(M_{L} 5.9\right)$ and during the Emilia seismic sequence of May-June 2012, geochemical field investigations were carried out into the epicentral area.

The soil-gas concentrations and flux measurements for liquefactions, ground fractures, and collapsed caves suggest a superficial origin of these phenomena. This is probably related to the stratigraphy of the shallowest layers of the Po Plain. The results gathered support the hypothesis that soil liquefactions are surficial phenomena [Bhattacharya et al. 2011] that affect only the shallowest layers of the ground (tens or hundreds of meters).

The results of the collapsed caves measurements show that the $\mathrm{CO}_{2}$ had remained essentially constant with respect to the 2008 survey, while the $\mathrm{CH}_{4}$ appeared to be higher after the seismic sequence. However, no hints of deep degassing can be inferred for the study area after the earthquake, as suggested by isotopical analyses carried out both on soil liquefaction and in collapsed caves.

The results obtained in this study constitute the starting point for subsequent geochemical surveys, which will be carried out over time, both on liquefactions and collapsed caves, to assess the temporal variations and to better understand the geochemical processes related to the seismic sequence.

Acknowledgements. We warmly thank the owners of the fields and gardens who allowed the gas measurements. We particularly appreciated the kindness and the humanity of people we met, despite the tremendous tragedy they were experiencing. We also thank Thomas Wiesberg and an anonymous reviewer, who strongly improved the quality of the manuscript.

\section{References}

Annunziatellis, A., S.E. Beaubien, S. Bigi, G. Ciotoli, M. Coltella, S. Lombardi (2008). Gas migration along fault systems and through the vadose zone in the Latera caldera (central Italy): Implications for $\mathrm{CO}_{2}$ geological storage, Int. J. Greenh. Gas Con., 2, 353-372.

Baldocchi, D.D., and T.P. Meyers (1991). Trace gas exchange above the floor of a deciduous forest, Evaporation and $\mathrm{CO}_{2}$ flux, J. Geophys. Res., 96, 7271-7285.

Basili, R., G. Valensise, P. Vannoli, P. Burrato, U. Fracassi, S. Mariano, M.M. Tiberti and E. Boschi (2008). The Database of Individual Seismogenic Sources (DISS), version 3: summarizing 20 years of research on Italy's earthquake geology, Tectonophysics, 453 (1-4), 20-43; doi: 10.1016/ j.tecto.2007.04.014.

Beaubien, S.E., G. Ciotoli and S. Lombardi (2003). Carbon dioxide and radon gas hazard in the Alban Hills area (central Italy), JVGR, 123, 63-80.

Boccaletti, M., M. Bonini, G. Corti, P. Gasperini, L. Martelli, L. Piccardi, C. Tanini and G. Vannucci (2004). Seismotectonic map of the Emilia-Romagna region, scale 1:250,000, Consiglio Nazionale delle Ricerche, Firenze, Italy.

Bhattacharya, S., M. Hyodo, K. Goda, T. Tazoh, C.A. Taylor (2011). Liquefaction of soil in the Tokyo Bay area from the 2011 Tohoku (Japan) earthquake, Soil Dynam. Earthqu. Eng., 31, 1618-1628.

Bonori, O., M. Ciabatti, S. Cremonini, R. Di Giovanbattista, G. Martinelli, S. Maurizzi, G. Quadri, E. Rabbi, P.V. Righi, S. Tinti and E. Zantedeschi (2000). Geochemical and geophysical monitoring in tectonically active areas of Po Valley (northern Italy). Case histories linked to gas emission structures, Geogr. Fis. Din. Quat., 23, 3-20. 
Burrato, P., F. Ciucci and G. Valensise (2003). An inventory of river anomalies in the Po Plain, northern Italy: Evidence for active blind thrust faulting, Annals of Geophysics, 46 (5), 865-882; doi:10.4401/ag-3459.

Cardellini, C., G. Chiodini, F. Frondini, D. Granieri, J. Lewicki and L. Peruzzi (2003). Accumulation chamber measurements of methane fluxes: application to volcanic-geothermal areas and landfills, Appl. Geochem., 18, 45-54.

Carminati, E., D. Scrocca and C. Doglioni (2010). Compaction-induced stress variations with depth in an active anticline: northern Apennines, Italy, J. Geophys. Res., 115, B02401.

Castellarin, A., E. Rabbi, S. Cremonini, L. Martelli and F. Piattoni (2006). New insights into the underground hydrology of the eastern Po Plain (northern Italy), B. Geofis. Teor. Appl., 47, 271-298.

Ciotoli, G., G. Etiope, M. Guerra and S. Lombardi (1999). The detection of concealed faults in the Ofanto Basin using the correlation between soil-gas fracture surveys, Tectonophysics, 301, 321-332.

Ciotoli, G., S. Lombardi, S. Morandi and F. Zarlenga (2005). A multidisciplinary statistical approach to study the relationships between helium leakage and neo-tectonic activity in a gas province: The Vasto Basin, Abruzzo-Molise (central Italy), AAPG Bull., 88, 355-372.

Ciotoli, G., S. Lombardi and A. Annunziatellis (2007). Geostatistical analysis of soil gas data in a high seismic intermontane basin: Fucino Plain, central Italy, J. Geophys. Res., 112, B05407.

Duddridge, G.A., P. Grainger and E.M. Durrance (1991). Fault detection using soil gas geochemistry, Q. J. Eng. Geol. Hidroge., 24, 427-435.

Durrance, E.M., and R.G. Gregory (1990). Helium and radon transport mechanisms in hydrothermal circulation systems of Southwest England, In: Geochemistry of Gaseous Elements and Compounds, Theophrastus Publ., Athens, 337-352.

Etiope, G., and S. Lombardi (1995). Evidence for radon transport by carrier gas through faulted clays in Italy, J. Radioanal. Nucl. Ch., 193, 291-300.

Febo, C. (1999). Caratteri Idrogeologici e Idrochimici di Dettaglio delle Falde Acquifere Superficiali della Zona di Finale Emilia - MO, Bachelor thesis, Tutor E. Rabbi, Università di Bologna.

Hazen, A. (1920). Hydraulic-Fill Dams, T. Am. Soc. Civ. Eng., $83,1719-1745$.

Hermansson, H.P., G. Akerblom, J. Chyssler and A. Linden (1991). Geogas, a carrier or a tracer?, SKN Report 51.

Hinkle, M. (1994). Environmental conditions affecting concentrations of $\mathrm{He}, \mathrm{CO}_{2}, \mathrm{O}_{2}$ and $\mathrm{N}_{2}$ in soil gases, Appl. Geochem., 9, 53-63.

Hutchinson, G.L., G.P. Livingston, R.W. Healy and R.G. Striegl (2000). Chamber measurement of surface atmos- phere trace gas exchange: numerical evaluation of dependence on soil, interfacial layer and source/sink properties, J. Geophys. Res., 105, 8865-8875.

Lombardi, S., and N. Voltattorni (2010). Rn, He and $\mathrm{CO}_{2}$ soil gas geochemistry for the study of active and inactive faults, Appl. Geochem. 25, 1206-1220.

Martelli, L. (2002). Indagine relativa ai fenomeni di scavernamento in atto nella Provincia di Bologna. Relazione Conclusiva all'Amministrazione Provinciale, Settore Ambiente, Servizio Assetto Idrogeologico.

Quattrocchi, F., M. Guerra, L. Pizzino and S. Lombardi (1999). Radon and helium as pathfinders of fault systems and groundwater evolution in different Italian areas, Il Nuovo Cimento, 22 (3-4), 309-316.

Reimer, G.M. (1980). Use of soil-gas helium concentrations for earthquake prediction: limitations imposed by diurnal variation, J. Geophys. Res., 85, 3107-3114.

Reimer, G.M. (1990). Reconnaissance techniques for determining soil-gas radon concentrations: an example from Prince Georges County, Maryland, Geophys. Res. Lett., $17,809-812$.

Scrocca, D., E. Carminati, C. Doglioni and D. Marcantoni (2007). Slab retreat and active shortening along the central-northern Apennines, In: O. Lacombe, J. Lavé, F.M. Roure and J. Verges (eds.), Thrust Belts and Foreland Basins: From Fold Kinematics to Hydrocarbon Systems, Frontiers in Earth Sciences, Springer, Berlin, 471-487.

${ }^{\star}$ Corresponding author: Alessandra Sciarra, Istituto Nazionale di Geofisica e Vulcanologia, Sezione Roma 1, Roma, Italy; email: alessandra.sciarra@ingvit.

(C) 2012 by the Istituto Nazionale di Geofisica e Vulcanologia. All rights reserved. 